\title{
OPTIMASI AKTIVITAS BAKTERIOSIN YANG DIHASILKAN OLEH Lactobacillus brevis DARI ES PISANG IJO
}

\author{
Nia Purnama Ningsih ${ }^{1}$, Rafika Sari ${ }^{2}$, Pratiwi Apridamayanti ${ }^{3}$ \\ ${ }^{1,2,3}$ Program Studi Farmasi, Fakultas Kedokteran, Universitas Tanjungpura, Pontianak. \\ J1. Profesor Dokter H. Hadari Nawawi, Bansir Laut, Pontianak Tenggara Kalimantan Barat 78115 \\ ${ }^{1}$ e-mail: Niapurnama1901@yahoo.com
}

\begin{abstract}
Abstrak
Penelitian bertujuan untuk mengoptimasi aktivitas bakteriosin yang dihasilkan Lactobacillus brevis dengan variasi $\mathrm{pH}$ dan suhu serta uji konfirmasi enzim proteolitik. Kultur bakteri berumur 24 jam yang telah diisolasi dari es pisang ijo pada penelitian sebelumnya ditumbuhkan pada media De Man Rogosa Sharp Agar (MRSA) dengan metode striking dan diinkubasi pada suhu $32^{\circ} \mathrm{C}$ selama 24 jam. Uji aktivitas antibakteri terhadap bakteri indikator menggunakan metode difusi agar. Hasil penelitian menunjukkan Lactobacillus brevis berpotensi digunakan sebagai agen biopreservatif pada bahan pangan yang dapat menghambat Gram positif (Staphylococcus aureus) dengan aktivitas tertinggi pada $\mathrm{pH} 6$ dan suhu $40^{\circ} \mathrm{C}$ dengan zona hambat secara berturut turut yaitu $12,10 \mathrm{~mm}$ dan $12,40 \mathrm{~mm}$ dan Gram negatif (Escherichia coli) dengan aktivitas tertinggi pada $\mathrm{pH} 6$ dan suhu $40^{\circ} \mathrm{C}$ dengan zona hambat secara berturut turut yaitu $9,30 \mathrm{~mm}$ dan $8,5 \mathrm{~mm}$. Konfirmasi menggunakan enzim zona hambat ketika ditambahkan enzim katalase yaitu sebesar $7 \mathrm{~mm}$ dan pada bakteri Escherichia coli dan $10 \mathrm{~mm}$ pada bakteri Staphylococcus aureus. Brevicin diinaktifkan oleh enzim tripsin sehingga tidak terbentuk zona hambat pada koloni.
\end{abstract}

Kata Kunci: Bakteriosin, bakteri asam laktat, pisang ijo

\begin{abstract}
This study aimed at optimizing bacteriocin activity produced by Lactobacillus brevis with a variety of $\mathrm{pH}$, temperature and the confirm proteolytic enzymes test. The 24hour-old bacterial culture isolated from green banana ice in the previous study was grown on the media of De Man Rogosa Sharp Agar (MRSA) by striking method and incubated at $32^{\circ} C$ for 24 hours. Antibacterial activity test against indicator bacteria using agar diffusion method. The results shows that Lactobacillus brevis can potentially be used as biopreservatif agent in food which can inhibit the positive bacteria (Staphylococcus aureus) with highest activity at pH 6 and temperature $40^{\circ} \mathrm{C}$ with inhibitory zone are $12,10 \mathrm{~mm}$ and $12,40 \mathrm{~mm}$ and Gram negative (Escherichia coli) with highest activity at $\mathrm{pH} 6$ and temperature $40^{\circ} \mathrm{C}$ with inhibitory zone are $9,30 \mathrm{~mm}$ and $8,5 \mathrm{~mm}$. Bacteriocin has a resistor zone when added by $7 \mathrm{~mm}$ catalase enyzme on Escherichia coli bacteria and $10 \mathrm{~mm}$ on Staphylococcus aureus. Brevicin is inactivated by trypsin, thereby no inhibition zone around the colonies.
\end{abstract}

Keyword: Bacteriocins, lactic acid bacteria, es pisang ijo.

\section{PENDAHULUAN}

Bahan pangan yang dikonsumsi terdiri dari beragam jenis makanan maupun minuman dengan berbagai cara pengolahannya. Bahan pangan memiliki 
manfaat yang besar tetapi juga dapat bertindak sebagai media perantara untuk pertumbuhan mikroorganisme patogen. Pertumbuhan mikroorganisme dapat dicegah dengan penambahan bahan pengawet. Bahan pengawet makanan yang sering digunakan adalah natrium benzoat dan kalium benzoat. Natrium benzoat dan kalium benzoat yang dikonsumsi melebihi batas maksimum akan berdampak negatif misalnya keracunan hingga kerusakan organ (Zenginet al., 2011 hal 763769).

Bakteri asam laktat mempunyai kemampuan untuk memproduksi bahan pengawet alami yang dikenal sebagai bakteriosin. Bakteriosin berperan sebagai biopreservatif karena mampu menghambat pertumbuhan bakteri khususnya bakteri patogen meliputi bakteri Gram positif dan Gram negatif. Bakteriosin memiliki beberapa keunggulan dari bahan pengawet kimia yaitu tidak menyebabkan toksik pada makanan, merupakan senyawa protein yang mudah didegradasi enzim proteolitik, tidak membahayakan organ pencernaan, bakteriosin juga memberikan efek antimikroba tanpa menimbulkan perubahan cita rasa dan tampilan yang nyata pada produk yang dihasilkan sehingga dapat diaplikasikan dalam makanan (Smid, et al., 2007 hal 402).

Indonesia kaya akan kuliner yang berasal dari berbagai daerah. Kuliner yangtersedia selain memiliki cita rasa yang lezat juga dapat memberikan dampak yang baik bagi kesehatan, salah satunya adalah es pisang ijo. Es pisang ijo mengandung isolat unggulan yaitu Lactobacillus brevis yang menghasilkan bakteriosin dan memiliki aktivitas sebagai antibakteri terhadap bakteri patogendan pembusuk yang biasanya mencemari makanan maupun minuman yang terdiri dari bakteri Gram negatif dan bakteri Gram positif. Lactobacillus brevis yang ditemukan pada es pisang ijo memiliki potensi sebagai bahan pengawet alami dan memiliki kemampuan dalam menghambat bakteri patogen seperti Escherichia coli dan Staphylococcus aureus sehingga perlu dilakukan optimasi aktivitas bakteriosin yang dihasilkan oleh Lactobacillus brevis dari es pisang ijo untuk mengetahui kondisi optimum aktivitas bakteriosin sebagai antibakteri. Penelitian bertujuan untuk mengoptimasi aktivitas bakteriosin yang dihasilkan Lactobacillus brevis dengan variasi $\mathrm{pH}$ dan suhu serta uji konfirmasi enzim proteolitik. 


\section{METODE}

Alat dan bahan yang digunakan dalam penelitian adalah Cawan petri (Iwaki pyrex), jarum Ose, kaca objek, tabung reaksi, tabung erlemeyer (Iwaki pyrex), gelas beaker (Iwaki pyrex), autoklaf, mikroskop, inkubator, Laminar Air Flow (LAF), bunsen, lemari pendingin, mikro sentrifugasi, filter bakteri, dan jangka sorong.

Isolat Lactobacillus brevisdari es pisang ijo, media De Man Rogosa and Sharpe (MRS) agar, media De Man Rogosa and Sharpe (MRS) broth, akuades, kristal violet, iodium, etanol 95\%, safranin, dapar fosfat, $\mathrm{NaOH}, \mathrm{HCl}$, dan media Mueller Hinton Agar (MHA).

Kultur bakteri berumur 24 jam yang telah diisolasi dari es pisang ijo pada penelitian sebelumnya ditumbuhkan pada media De Man Rogosa Sharp Agar (MRSA) dengan metode striking dan diinkubasi pada suhu $32^{\circ} \mathrm{C}$ selama 24 jam, kemudian diambil satu koloni BAL dan dimasukkan ke De Man Rogosa Sharp Broth (MRSB). Kultur kemudian diinkubasi pada suhu $32^{\circ} \mathrm{C}$ selama 24 jam.

Bakteri diidentifikasi dengan pewarnaan Gram. Pewarnaan Gram dilakukan dengan cara satu tetes kristal violet ditambahkan pada preparat yang telah diolesi isolat BAL yang berumur 24 jam. Preparat dibiarkan selama 1 menit dan dicuci dengan akuades. Sebanyak 1 tetes iodium ditambahkan kedalam preparat, dibiarkan selama 2 menit dan dibilas dengan akuades. Preparat dicuci ulang menggunakan etanol $95 \%$ dan dibilas pada air mengalir. Isolat BAL ditambahkan safranin, dibilas pada air yang mengalir.

Kultur Lactobacillus brevis diinokulasikan ke MRS cair 5,0 mL kemudian divortex hingga homogen dan diinkubasi pada suhu $32^{\circ} \mathrm{C}$ selama 24 jam. Kultur cair disentrifugasi dengan kecepatan $10000 \mathrm{rpm}$ pada suhu $4^{\circ} \mathrm{C}$ selama 15 menit. Filtrat dinetralkan hingga $\mathrm{pH}$ 7,0 menggunakan $\mathrm{pH}$ meter dengan menambahkan larutan $\mathrm{NaOH} 1 \mathrm{~N}$. Filtrat pH 7 disterilkan dengan filter bakteri berdiameter 0,22 $\mu \mathrm{m}$ ke dalam tabung steril untuk memperoleh supernatan antibakteri.

Uji aktivitas antibakteri terhadap bakteri indikator menggunakan metode difusi agar. Sebanyak $20 \mu \mathrm{L}$ supernatan antibakteri diteteskan pada kertas cakram steril berdiameter $6 \mathrm{~mm}$. Kertas cakram diletakkan pada media MHA yang 
mengandung bakteri uji (Escherichia coli danStaphylococcus aureus). Diameter zona bening yang dihasilkan di sekitar kertas cakram diukur dengan menggunakan jangka sorong setelah diinkubasi selama 24 jam suhu $37^{\circ} \mathrm{C}$.

Sebanyak $250 \mu \mathrm{L}$ supernatan bakteriosin dicampur dengan $750 \mu \mathrm{L}$ enzim konsentrasi $1 \mathrm{mg} / \mathrm{mL}$ dilarutkan dalam dapar pospat $\mathrm{pH}$ 7,6 untuk enzim tripsin dan dapar pospat pH 7 untuk enzim katalase kemudian diinkubasi selama 5 jam pada suhu $25^{\circ} \mathrm{C}$. Filtrat disterilkan dengan filter Millipore berdiameter 0,22 $\mu \mathrm{m}$ ke dalam tabung steril. Kertas cakram diletakkan diatas media MHA yang mengandung bakteri patogen (Escherichia coli danStaphylococcus aureus). Sebanyak $20 \mu \mathrm{L}$ supernatanantimikroba diteteskan pada kertas cakram steril. Diameter zona bening yang dihasilkan di sekitar kertas cakram diukur dengan menggunakan jangka sorong setelah diinkubasi pada suhu $37^{\circ} \mathrm{C}$ selama 24 jam.

Sebanyak $5 \mathrm{ml}$ larutan supernatan bakteriosin kasar pada tabung yang berbeda, masing-masing diatur $\mathrm{pH}$ nya pada $\mathrm{pH}$ 2, 4, 6, 8, dan 10 menggunakan larutan $\mathrm{NaOH} 1 \mathrm{~N}$ atau $\mathrm{HCl} 1 \mathrm{~N}$. Setelah diatur $\mathrm{pH}$ bakteriosin tersebut diinkubasi selama 4 jam pada suhu kamar, selanjutnya aktivitas bakteriosin diuji menggunakan metode difusi agar.

Sebanyak $5 \mathrm{ml}$ supernatan bakteriosin masing-masing dipanaskan pada suhu $40,60,80$, dan $100^{\circ} \mathrm{C}$ selama 30 menit di waterbath thermostatic dan $121^{\circ} \mathrm{C}$ selama 15 menit di autoklaf. Aktivitas bakteriosin kemudian diuji dengan metode difusi agar menggunakan bakteri uji Escherichia coli danStaphylococcus aureus.

\section{HASIL DAN PEMBAHASAN}

Media yang digunakan pada penelitian ini terdiri dari media De Man Rogosa and Sharpe (MRS) agar, media De Man Rogosa and Sharpe (MRS) broth dan media Mueller Hinton Agar (MHA). Media tersebut memiliki fungsi dan kandungan yang berbeda. Media MRSA dan media MRSB merupakan media selektif yang hanya dapat menumbuhkan bakteri asam laktat (BAL) tetapi kedua media ini digunakan pada tujuan yang berbeda. Media MRSA digunakan untuk menumbuhkan dan mengisolasi isolat bakteri asam laktat yang tumbuh berkoloni sedangkan media MRSB merupakan media berbentuk cair yang digunakan untuk 
memproduksi dan memudahkan BAL untuk melepaskan bakteriosin pada media cair tersebut. Media MHA merupakan media yang digunakan untuk menumbuhkan bakteri patogen yaitu bakteri E.coli dan S.aureus. Media MHA mengandung komposisi dan nutrisi yang dapat menunjang pertumbuhan bakteri patogen pada penelitian ini. Setelah proses sterilisasi pada alat dan media dilakukan serangkaian pengujian meliputi identifikasi isolat, konfirmasi BAL, pengambilan bakteriosin, uji aktivitas antimikroba terhadap bakteri E.coli dan S.aureus, uji sensitivitas bakteriosin terhadap enzim proteolitik dan optimasi bakteriosin yang terdiri dari variasi $\mathrm{pH}$ dan suhu pemanasan.

Hasil peremajaan isolat Lactobacillus brevis dari es pisang ijo yang telah diinkubasi pada suhu $32^{\circ} \mathrm{C}$ selama 24 jam yaitudiperoleh isolat bakteri yang tumbuh secara berkoloni kasar bewarna putih pada MRSA. Media MRSA merupakan media yang digunakan untuk mendukung pertumbuhan bakteri asam laktat termasuk genus Lactobacillus, mengandung pepton, beef extract, yeast extract, dekstrosa, tween 80, ammonium sitrat, magnesium sulfat, mangan sulfat, dipotassium fosfat dan sodium asetat (Goktepe, et al., 2005 hal 54). Kultur BAL (Bakteri Asam Laktat) yang diperoleh dikonfirmasi dengan pewarnaan Gram untuk memastikan isolat BAL yang dihasilkan pada saat peremajaan tersebut merupakan isolat Lactobacillus brevis. Pewarnaan Gram dilakukan untuk melihat bentuk sel dan sifat yang dimiliki oleh bakteri.

Hasil uji pewarnaan Gram menunjukkan bahwa isolat Lactobacillus brevis merupakan bakteri Gram positif yang ditandai warna ungu pada sel bakteri yang diamati secara mikroskopik menggunakan mikroskop. Bakteri Gram positif mengalami denaturasi protein pada dinding selnya oleh pencucian dengan alkohol 96\%. Protein tersebut mengakibatkan pori-pori mengecil sehingga kompleks kristal violet terbentukdan sel bakteri tetap bewarna ungu. Bakteri Gram positif juga memiliki peptidoglikan yang tebal dan permeabilitas yang rendah sehingga kompleks kristal violet dan iodium tetap tertahan pada sel dan tidak dapat keluar.Pengamatan secara mikroskopik juga dapat menentukan bentuk sel bakteri. Berdasarkan hasil pengamatan secara mikroskopik diperoleh hasil bahwa 
Lactobacillus brevis termasuk dalam bakteri Gram positif dan memiliki bentuk batang (Assani,1994 hal 24-25).

Tabel 1. Hasil Uji Aktivitas Bakteriosin terhadap E.coli dan S.aureus

\begin{tabular}{cccc}
\hline Bakteri Uji & \multicolumn{3}{c}{ Zona Hambat $(\mathbf{m m})$} \\
\cline { 2 - 4 } & $\mathbf{I}$ & II & $\mathbf{x} \pm$ SD \\
\hline Escherichia coli & 8,75 & 8,60 & $8,67 \pm 0,106$ \\
\hline Staphylococcus aureus & 11,15 & 11,10 & $11,12 \pm 0,035$ \\
\hline Keterangan: $\mathrm{x}$ = rata-rata & & \multicolumn{2}{|c}{$\mathrm{SD}=$ Standar Deviasi }
\end{tabular}

Hasil pengujian aktivitas antimikroba terhadap bakteri patogen isolat Lactobacillus brevis memiliki spektrum yang luas. Dibuktikan dengan terbentuknya zona bening di sekitar cakram pada kedua bakteri indikator yang terdiri dari bakteri Gram positif yaitu Staphylococcus aureusdan bakteri Gram negative yaitu Escherichia coli. Hasil uji aktivitas antibakteri yang diperoleh juga sesuai dengan penelitian yang telah dilakukan oleh Ogunbawo (2003) hal 219-227 yang menyebutkan bahwa bakteriosin dari Lactobacillus brevis dapat menghambat bakteri patogenEscherichia coli dan Staphylococcus aureus dan hasil penelitian lain yang mendukung yaitu Nuraida (2007) Lactobacillus brevis yang diisolasi secara invitro dapat menghambat pertumbuhan bakteri patogen seperti Escherichia coli dan Staphylococcus aureus.

Penghambatan bakteriosin terhadap bakteri Gram positif dan Gram negatif memiliki mekanisme yang berbeda. Perbedaan mekanisme penghambatan pada bakteri Gram positif dan bakteri Gram negatif mengakibatkan perbedaan zona hambat yang terbentuk dimana bakteri Gram negatif memiliki ketahanan yang lebih baik terhadap senyawa antimikroba sehingga zona hambat yang terbentuk pada bakteri Gram negatif lebih kecil dari penghambatan oleh bakteri Gram positif. 
Tabel 2. Hasil Uji Aktivitas Bakteriosin terhadap Enzim Tripsin dan Katalase

\begin{tabular}{lccc}
\hline \multicolumn{1}{c}{ Bakteri Uji } & \multicolumn{2}{c}{ Zona Hambat $(\mathbf{m m})$} \\
& I & II & $\mathbf{x} \pm \mathbf{S D}$ \\
\hline $\begin{array}{l}\text { Escherichia coli } \\
\text { Staphylococcus }\end{array}$ & 7,0 & 7,35 & $7,17 \pm 0,247$ \\
aureus & 10,25 & $10,13 \pm 0,176$ \\
\hline \multicolumn{2}{c}{ Keterangan: $\mathrm{x}=$ rata-rata } & $\mathrm{SD}=$ Standar Deviasi
\end{tabular}

Bakteriosin yang dihasilkan oleh Lactobacillus brevis diuji aktivitasnya terhadap penambahan enzim-enzim yang terdiri dari enzim tripsin dan enzim katalase. Tujuan dari uji sensitivitas antimikroba terhadap enzim proteolitik adalah memastikan bahwa substansi antibakteri yang dihasilkan oleh Lactobacillus brevis merupakan bakteriosin. Penambahan enzim proteolitik dapat menghilangkan aktivitas bakteriosin dengan berkurang atau hilangnya zona hambat disekitar cakram.

Hasil pengujian penambahan enzim proteolitik meliputi enzim tripsin dan katalase pada bakteriosin yaitu adanya zona hambat pada enzim tripsin yang merupakan enzim proteolitik pengurai protein. Pada pengujian menggunakan enzim tripsin brevicin yang dihasilkan oleh Lactobacillus brevis diuraikan oleh enzim tripsin sehingga zona hambat disekitar cakram tidak terbentuk, hal ini membuktikan bahwa isolat menghasilkan bakteriosin yang merupakan protein alami dan merupakan protein yang mampu terdegradasi oleh keberadaan enzim proteolitik. Hasil pengujiansesuai dengan penelitian Duraisamyet al., (2013) hal 175-185 yaitu pada penambahan enzim tripsin tidak terdapat zona hambat disekitar cakram sedangkan pada penambahan enzim katalase pada bakteriosin terbentuk zona penghambatan disekitar cakram. Penambahan enzim katalase pada bakteriosin menghasilkan zona hambat dengan zona rata-rata sebesar 7,17 mm pada bakteri Escherichia coli dan sebesar 10,13 mm pada bakteri Staphylococcus aureus. Penambahan enzim katalase dilakukan untuk membuktikan bahwa zona jernih yang terbentuk bukan disebabkan oleh senyawa peroksida(Sari et al., 2011 hal 116-121). 
Berdasarkan hasil penelitian bakteriosin dari Lactobacillus brevis dapat memberikan zona hambat pada $\mathrm{pH} 2$ sampai dengan $\mathrm{pH} 8$ yang ditunjukkan dengan terbentuknya zona hambat disekitar cakram.Hal ini juga sesuai dan didukung oleh berbagai penelitian yaitu penelitian yang dilakukan oleh Ogunbawo (2003) hal 219-227 yang menyebutkan bahwa bakteriosin dari Lactobacillus brevis stabil pada pH 2 hingga pH 8.Penelitian Duraisamyet al., (2015) hal 175185 yang menyatakan bahwa Lactobacillus brevis konstan pada $\mathrm{pH}$ 3-8 dan memiliki aktivitas optimum pada pH 6. PenelitianFatima (2016) menyatakanbahwa Lactobacillus breviskonstan pada $\mathrm{pH}$ dengan rentang 2-8. Hasil yang diperoleh menunjukkan bakteriosin yang dihasilkan oleh Lactobacillus brevis cocok digunakan sebagai pengawet makanan alami pada bahan $\mathrm{pH}$ asam dan basa diantaranya sebagai pengawet pada sayuran, buah, daging, sosis, fermentasi pada pembuatan roti dan makanan kaleng (Buckle,1987).

Proses pengawetan pada bahan pangan terkadang melibatkan pemanasan sehingga perlu diketahui kestabilan bakteriosin yang diperoleh dari Lactobacillus brevis pada berbagai suhu pemanasan. Hasil yang diperoleh bakteriosin dari sampel es pisang ijo dapat tumbuh pada suhu pemanasan $40^{\circ} \mathrm{C}, 60^{\circ} \mathrm{C}, 80^{\circ} \mathrm{C}$ dan $100^{\circ}$ C.Hasil yang diperoleh juga sesuai dengan penelitian Duraisamyet al., (2015)hal 175-185bahwa Lactobacillus brevis konstan pada suhu $20^{\circ} \mathrm{C}$ sampai dengan suhu $100^{\circ} \mathrm{C}$ dan kondisi paling optimum berada pada suhu $40^{\circ}$ C.Lactobacillus brevis memiliki sifat tahan terhadap panas pada suhu $40^{\circ} \mathrm{C}$ hingga $100^{\circ} \mathrm{C}$ stabil terhadap panas merupakan salah satu karakteristik bakteriosin yang diperlukan sebagai biopreservasi pangan disebabkan umumnya proses produksi pangan menggunakan suhu pemanasan. Bakteriosin yang dihasilkan oleh Lactobacillus brevis berpotensi dapat digunakan sebagai bahan biopreservasi pada produk pangan yang melibatkan proses pemanasan.

\section{SIMPULAN}

Bakteriosin yang dihasilkan oleh Lactobacillus brevis dari es pisang ijo memiliki aktivitas antibakteri terhadap Escherichia coli dan Staphylococcus aureus. Bakteriosin yang dihasilkan oleh Lactobacillus brevis berpotensi 
digunakan sebagai agen biopreservatif dapat menghambat dengan aktivitas tertinggi terhadap Escherichia colidan Staphylococcus aureuspada pH 6 dan suhu $40^{\circ} \mathrm{C}$. Aktivitas bakteriosin yang dihasilkan oleh Lactobacillus brevis hilang dengan penambahan enzim tripsin dan memiliki zona hambat ketika ditambahkan enzim katalase.

\section{DAFTAR PUSTAKA}

Assani S. (1994). Ultrastruktur, morfologi dan pewarnaan Gram. Dalam (Staff Pengajar FKUI) Buku Ajar Mikrobiologi Kedokteran. Edisi Revisi. Jakarta: Binarupa Aksara. 24-25.

Buckle, K.A., R.A. Edwards, G.H. Fleet, M. \& Wooton. (1987). Ilmu Pangan. Terjemahan: H. Purnomo dan Adiono. Jakarta: Universitas Indonesia Press.

Duraisamy S., Gurusamy R., \& Sentihilkumar B. (2013). Antagonistic Effect of Brevicin on Gram Positive and Gram negative food borne bacteria and its biopreservative efficacy in milk. African Journal of biotechnology.

Duraisamy S., Kasi M., Balakrishnan., Al shohaibani S \& Ramasamy G. (2015). Optimization of Lactobacillus brevis NS01 Brevicin Production and Its Application in Apple Juice Biopreservation Using Food-Grade Clarifying Agent Silica as a Carrier. Food Bioprocess Technol Journal,12(2), 175185.

Fatima D. (2016). Characterization Of Bacteriocin Produced By Lactobacillus Brevis Isolated From Traditional Fermented Tomatoes Juice. Sci Agri, 15(3), 401-408.

Goktepe I, Vijay KJ, \& Mohamed A. (2005). Probiotics in Food Safety and Human Health. Boca Raton: CRC Press.

Nuraida L, Susanti \& Hartanti AW. (2007). Lactic acid bacteria and bifidobacteria Profile of Breast Milk and Their potency as probiotics 10 ${ }^{\text {th }}$ Asean food conference. Kuala Lumpur Malaysia: Food for Mankind contribution of Science and technology.

Ogunbanwo, S.T., A.I. Sanni \& A.A. Onilude. (2003). Characterization of Bacteriosin Produced by Lactobacillus plantarum F1 and Lactobacillus brevis OGI.Afric. J. Biotechnol, 2(8), 219-227.

Sari, R., Cesilia, A., Maksum, R., \& Amarila, M. (2011). Skrining Bakteriosin dari beberapa galur bakteri asam laktat isolat lokal genus Streptococcus dan Weissella. Jurnal Ilmu Kefarmasian Indonesia, 9(2), 116-121. 
Smid, E.J. and L.G.M. Gorris. (2007). Natural antimicrobial for food preservation. In:Rahman, M.S. (Editor). Handbook of Food Preservation. 2nd Edition. New York: CRC Press.

Zengin N, Yuzbasioglu D, Unal. (2011). The evaluation of two food preservatives: sodium benzoate and potassium benzoate. Journal Elsevier, 49, 763-769. 